\title{
Effects of dietary inclusion level of a mixture of probiotic cultures and enzymes on broiler chickens immunity response
}

\author{
Alireza Seidavi ${ }^{1}$ - Mohammad Dadashbeiki ${ }^{2}$. \\ Mohammad-Hossein Alimohammadi-Saraei ${ }^{1}$ - René van den Hoven ${ }^{3}$. \\ Rita Payan-Carreira $^{4,5}$ • Vito Laudadio ${ }^{6}$ - Vincenzo Tufarelli ${ }^{6}$
}

Received: 3 November 2016 / Accepted: 2 December 2016/Published online: 13 December 2016

(C) Springer-Verlag Berlin Heidelberg 2016

\begin{abstract}
The current study was conducted to analyse the effect of a mixture of probiotic cultures and enzymes (Probio Enzyme, XVET GmbH, Germany) on the immune response and weight of central lymphoid organs and liver in broilers. A total of 270 male chickens were randomly divided into nine groups, with three replicates of 10 birds each. Treatment groups were fed for either 22 or 42 days with different levels of Probio Enzyme 250, 500, 750 and $1000 \mathrm{~g} /$ ton, whereas the control group fed a basal diet without Probio Enzyme. To analyse the effects of dietary supplementation on broilers humoral immune response, the antibodies titres for avian influenza (AI) and Newcastle disease virus (NDV) and to the sheep red blood cells (SRBC) challenge were assayed in birds from each experimental unit, along with the assessment of the weight of the main lymphoid organs and
\end{abstract}

Responsible editor: Philippe Garrigues

Alireza Seidavi

alirezaseidavi@iaurasht.ac.ir

$\triangle$ Vincenzo Tufarelli

vincenzo.tufarelli@uniba.it

1 Department of Animal Science, Rasht Branch, Islamic Azad University, Rasht, Iran

2 Department of Veterinary Science, Rasht Branch, Islamic Azad University, Rasht, Iran

3 Institute of Animal Nutrition, Veterinary University of Vienna, Vienna, Austria

4 Department of Zootechnics, Universidade de Trás-os-Montes e Alto Douro, Vila Real, Portugal

5 Animal and Veterinary Research Centre - CECAV, Vila Real, Portugal

6 Department of DETO, Section of Veterinary Science and Animal Production, University of Bari 'Aldo Moro', Valenzano, Bari, Italy liver. The addition of the Probio Enzyme mixture did not significantly affect the titres of the antibodies against AI and NDV at day 42, despite the wide individual variation observed specially on the antibody titres at day 33 . Treatments affected the production of IgG after the second challenge with SRBC $(P=0.003)$, which was transposed to the correspondent total Ig titres $(P=0.044)$. Conversely, a lower birds' body weight (BW) was found in the majority of treated groups compared to control $(P=0.031)$. The spleen was the only lymphoid organ showing differences in the absolute and relative weight $(P=0.003$ and $P=0.001$, respectively). No differences were found in thymus and Bursa of Fabricius weights. In conclusion, broilers treated with Probio Enzyme showed a satisfactory immune response compared with control, despite the wide variation found after the first vaccine challenge against AI. Moreover, the probiotic mixture dose and duration modulated differently the immune response and the spleen weight, unaffecting the central lymphoid organs weight.

Keywords Probiotics $\cdot$ Enzyme $\cdot$ Immunity $\cdot$ Antibody · Broiler

\section{Introduction}

Probiotic supplement for the development and stabilization of the intestinal flora is used particularly before birds' exposure to expected stressors such as transportation, new housing allocation or feed changes (Gaggìa et al. 2010; Jahromi et al. 2016). Although the gut microbiome is quite complex, comprising a multitude of bacteria, yeast and protozoa, various species of lactobacilli play a major role maintaining the equilibrium of intestinal biota and preventing the colonization of pathogens (Bai et al. 2013; Chen et al. 2014) such as pathogenic Escherichia coli and Salmonella spp. In parallel, 
particular mixtures of probiotic cultures increase feed conversion, growth performance and meat quality, increasing therefore the productivity of poultry (Gaggìa et al. 2010). This is possibly due to the fact that microorganisms naturally living in the intestinal tract are crucial for poultry digestion and immunity. However, conflict reports on the use of probiotic cultures suggest that influences may exist associated to the composition of the culture, the dose and/or duration of use (Gaggìa et al. 2010; Rezaei et al. 2015).

Industrial produced enzymes could aid the breakdown of a wide variety of feed components that typically would be left unused. A combination of lactobacilli and enzymes increases the efficacy of the digestion of different ingredients in feed (Chen et al. 2014); hence, it could improve feed conversion rate, increase the release of essential nutrients and reduce faecal losses and thus lower manure production, as well as less phosphorus and nitrogen excretion (Jin et al. 2000; Yang et al. 2009; Wang and Gu 2010). The effect of gut flora and immunity is presently a well-studied theme in human medicine (Guarner and Malagelada 2003; Macpherson and Harris 2004), where various mixtures with microorganisms, the so called probiotics, are used to improve or stabilize the gut microbiome. Probiotics and exogenous enzymes can also enhance broiler productivity and likely immunity too, that may represent an alternative to the use of sub-therapeutic doses of antibiotics (Talebi et al. 2008), meeting the growing public concerns on the contribution of this practice to the increasing antibiotic resistance. To date, information on the effect of a mixture of probiotic microorganisms and enzymes on the immunity of broilers are missing, to the authors' best knowledge. Therefore, the present study intended to determine the effect of different dietary levels of a probiotic-enzyme supplementation to broiler chickens on their immune competence.

\section{Material and methods}

\section{Animals and housing}

A total of two hundred seventy (270) 1-day-old Ross 308 (Aviagen, Newbridge, Scotland, UK 35805) male broiler chickens were purchased from a commercial hatchery. The chickens were placed in cages with dimensions of $1.0 \times 1.0 \mathrm{~m}$, providing a floor area of $0.1 \mathrm{~m}^{2}$ per bird, in a thermostatically controlled curtain sidewall poultry barn. Paper rolls were used for cage embedding. The birds were kept in cages, 10 chickens ( $41 \pm 0.5 \mathrm{~g}$ ) per cage, throughout of the study period (42 days). Each cage was assigned to a dietary treatment.

Heat from thermostatically controlled gasoline rocket heaters was used to maintain constant the ambient temperature within the poultry barn; temperature at $33^{\circ} \mathrm{C}$ at placement and decreased periodically to $23^{\circ} \mathrm{C}$ at 3 weeks of age, remaining thereafter constant until the end of the research period. The barn atmosphere was humidified via a water spray to preserve relative humidity between 55 and $65 \%$. A 23 -W fluorescent tubes in ceiling fixtures provided a constant $24 \mathrm{~h}$ light cycle on day one that was changed into a $21 \mathrm{~h} /$ day after day two until the end of the experiment. Forced air ventilation within the poultry barn was facilitated by wall-mounted fans on each end of the barn, establishing a tunnel ventilation.

\section{Feed and treatments}

A two-phase feeding program was used in this trial, consisting on a provision of starter diet from 1 to 21 days and grower diet from 22 to 42 days (Table 1). The diets met or exceeded Ross 308 catalogue recommendations (Table 2). A commercially available probiotic supplement with concentrated enzymes (Probio Enzyme, XVET GmbH, Germany) was administered to broilers through the feed. The product's composition included cultured Bacillus lichenformis, Bacillus subtilis, Enterococcus faecium, Lactobacillus acidophilus, $\beta$ glucanase (3.2.1.4), $\beta$-glucanase (3.2.1.6), $\beta$-xylanase (3.2.1.8), $\alpha$-amylase (3.2.1.1), protease and cellulose.

The effect of treatments was studied by a $4 \times 2$ factorial arrangement with four dietary Probio Enzyme levels (250, $500,750$ and $1000 \mathrm{~g} / \mathrm{ton})$ and two durations of treatment (14 and 42 days). Additionally, a control treatment without dietary Probio Enzyme supplementation was used. The trial comprised nine treatments with three replicates for each treatment, whereby each replicate included ten birds, as follows:

Treatment 1: T1, standard diet $+250 \mathrm{~g} /$ ton of Probio Enzyme for 14 days

Table 1 Feed ingredients of used diets during the starter (1-21 days of age) and grower (22-42 days of age) periods

\begin{tabular}{|c|c|c|}
\hline Ingredient $(\mathrm{g} / \mathrm{kg})$ & Starter period & Grower period \\
\hline Corn & 54.32 & 58.69 \\
\hline Soybean meal $(44 \% \mathrm{CP})$ & 39.43 & 31.87 \\
\hline Soybean oil & 2.16 & 5.83 \\
\hline Dicalcium phosphate & 2.05 & 1.68 \\
\hline Sodium chloride & 0.37 & 0.37 \\
\hline DL-methionine & 0.20 & 0.22 \\
\hline Lysine hydrochloride & 0.07 & 0.05 \\
\hline Vitamin premix $^{\mathrm{a}}$ & 0.25 & 0.25 \\
\hline Mineral premix ${ }^{\mathrm{b}}$ & 0.25 & 0.25 \\
\hline Mineral oysters & 0.90 & 0.79 \\
\hline
\end{tabular}

${ }^{\text {a }}$ Supplied per kilogram of diet 12,000 IU vitamin A, $10 \mathrm{mg}$ vitamin E, $2200 \mathrm{IU}$ vitamin D, $35 \mathrm{mg}$ niacin, $12 \mathrm{mg}$ D-pantothenic acid, $3.63 \mathrm{mg}$ riboflavin, $3.5 \mathrm{mg}$ pyridoxine, $2.4 \mathrm{mg}$ thiamine, $1.4 \mathrm{mg}$ folic acid, $0.15 \mathrm{mg}$ biotin and $0.03 \mathrm{mg}$ vitamin $\mathrm{B}$

${ }^{\mathrm{b}}$ Supplied per kilogram of diet $60 \mathrm{mg}$ manganese, $40 \mathrm{mg}$ zinc, $1280 \mathrm{mg}$ iron, $8 \mathrm{mg}$ copper, $0.3 \mathrm{mg}$ iodine and $0.2 \mathrm{mg}$ selenium 
Table 2 Nutrient analysis of the diets during the starter (1-21 days of age) and grower (22-42 days of age) periods

\begin{tabular}{lll}
\hline Nutrient analysis & Starter period & Grower period \\
\hline Metabolizable energy (kcal/kg) & 2900 & 3200 \\
Crude protein (\%) & 22.16 & 19.02 \\
Calcium (\%) & 1.00 & 0.85 \\
Available phosphorus (\%) & 0.50 & 0.42 \\
DCAB (mEq/kg) & 236 & 202 \\
Lysine (SID ) (\%) & 1.15 & 0.96 \\
Methionine (SID) (\%) & 0.50 & 0.48 \\
Methionine + cysteine (SID) (\%) & 0.83 & 0.78 \\
Threonine (SID) (\%) & 0.79 & 0.71 \\
\hline
\end{tabular}

* SID standardized ileal digestible

Treatment 2: T2, standard diet $+500 \mathrm{~g} /$ ton of Probio Enzyme for 14 days

Treatment 3: T3, standard diet $+750 \mathrm{~g} /$ ton of Probio Enzyme for 14 days

Treatment 4: T4, standard diet $+1000 \mathrm{~g} /$ ton of Probio Enzyme for 14 days

Treatment 5: T5, standard diet $+250 \mathrm{~g} /$ ton of Probio Enzyme for 42 days

Treatment 6: T6, standard diet $+500 \mathrm{~g} /$ ton of Probio Enzyme for 42 days

Treatment 7: T7, standard diet $+750 \mathrm{~g} /$ ton of Probio Enzyme for 42 days

Treatment 8: T8, standard diet $+1000 \mathrm{~g} /$ ton of Probio Enzyme for 42 days

Treatment 9 (control): T9, standard diet without Probio Enzyme for the entire period

\section{Vaccination program}

Birds were vaccinated at 1st, 11th and 19th days of age against Newcastle disease virus (NDV) and on the 1st and 19th days of age against infectious bronchitis. Gumboro vaccination was at 14 th and 25th days of age. Avian influenza (AI) vaccination was given at 1 st day of age.

\section{Immunity assays}

The measurement of the magnitude of the immune response was performed as described by Pourhossein et al. (2015). Briefly, at 10 and 28 days of age, sheep red blood cells (SRBC) suspension (5\% phosphate-buffered saline) was injected into the breast muscle of six birds per treatment. Fourteen days after each sensitization ( 24 and 42 days, respectively) antibody titres against SRBC were determined. Total serum antibody titres to SRBC were determined by hemagglutination assay. In U-bottom microtiter plates, two- fold serial dilutions of heat-inactivated (at $56{ }^{\circ} \mathrm{C}$ ) serum in PBS $(0.01 \mathrm{~mol} / \mathrm{L}, \mathrm{pH} 7.4)$ were made to measure the total antibody or in PBS with 1.4\% 2-mercaptoethanol for the determination of immunoglobulin $\mathrm{G}$ ( $\mathrm{IgG}$ ) antibody titres. All antibody titres were recorded as ${ }^{2} \log$ of the highest dilution of serum that agglutinated an equal volume of a $0.5 \%$ SRBC suspension in PBS. The IgM titre was determined by the difference between total and $\operatorname{IgG}$ titre.

From each treatment group, three birds were randomly chosen for blood sampling, collected from the brachial vein. Serum was separated by centrifugation at $1300 \times g$ for $15 \mathrm{~min}$ following a $1 \mathrm{~h}$ incubation at room temperature and stored at $-20{ }^{\circ} \mathrm{C}$ until the analysis. The antibody titres against NDV and AI were measured by hemagglutination-inhibition test according to Cunningham (1971). Blood sampling was performed on days 17 (for NDV), 33 (for AI) and 42 (for NDV and AI), respectively. At the end of the experiment, at 42 days, three representative birds from each treatment were randomly chosen and killed by cervical dislocation. The final defeathered body weight (BW), as well as the weights of liver, thymus, spleen and bursa of Fabricius were recorded for the estimation of their relative weight.

\section{Statistical analysis}

Statistical computations were performed by using a statistical software (SPSS Statistics 1997, version 22.0 for Mac OS-X10.8). The normal distribution of data for each category of the independent variables was rejected by Kolmogorov-Smirnov and Shapiro-Wilks tests. Hence, the Kruskal-Wallis nonparametric method was used to determine the differences among treatments for the immune parameters tested in the current study. The response to SRBC and immune response against $\mathrm{AI}$ and NDV were analysed after the 2 nd vaccination for pattern recognition as the use of the medians of the organs' weight per treatment.

\section{Results}

The results from this study are summarized in Tables 3, 4 and 5 , respectively. In overall, antibody titres for AI and NDV were independent by the treatment duration, except for the AI titres at day $33(P=0.027)$ and by the amount of the Probio Enzyme complex used in these experiments (Table 3). Wide individual variations were recorded within the treatment groups for both the influenza and the NDV antibody titres by day 33. Nevertheless, at day 33, most of the birds had produced antibodies against AI, while at day 42, all birds showed an active immune response with titres varying from 1:8 to 1:16. The vaccine-induced antibody titres did not differ among the nine treatment groups for influenza or NDV (Table 3). At day 17, most birds had no antibody titres against 
Table 3 Influence of Probio Enzyme treatments on the immune response after vaccination (avian influenza and Newcastle disease virus) of broilers. Values represent the median [mean rank]

\begin{tabular}{|c|c|c|c|c|c|}
\hline \multirow[t]{2}{*}{ Treatments } & & \multicolumn{2}{|c|}{ Antibody titres against AI } & \multicolumn{2}{|c|}{ Antibody titres against NDV } \\
\hline & & Day 33 & Day 42 & Day 17 & Day 42 \\
\hline \multirow[t]{3}{*}{ Length (day) } & Control & $2[15.33]^{\mathrm{a}, \mathrm{b}}$ & $3[11.00]$ & $0[12.50]$ & $4[13.50]$ \\
\hline & Short (14) & $1[9.83]^{\mathrm{a}}$ & $4[15.50]$ & $0[13.62]$ & $4[14.42]$ \\
\hline & Long (42) & $2[17.83]^{\mathrm{b}}$ & $3.5[13.25]$ & $0.5[14.75]$ & $4[13.78]$ \\
\hline$P$ value & & 0.027 & 0.522 & 0.850 & 0.966 \\
\hline \multirow[t]{5}{*}{ Probio Enzyme (g/ton) } & 0 & $2[15.33]$ & $3[11.00]$ & $0[12.50]$ & $4[13.50]$ \\
\hline & 250 & $2[17.83]$ & $4[15.50]$ & $0[12.50]$ & $4[17.25]$ \\
\hline & 500 & $1[11.67]$ & $4[15.50]$ & $0.5[14.75]$ & $4[11.50]$ \\
\hline & 750 & $1[9.83]$ & $3.5[13.25]$ & $0.5[14.75]$ & $4[16.75]$ \\
\hline & 1000 & $1.5[16.00]$ & $3.5[13.25]$ & $0.5[14.75]$ & $4[10.75]$ \\
\hline$P$ value & & 0.318 & 0.861 & 0.957 & 0.435 \\
\hline $\mathrm{T} 1$ & & $1[14.17]$ & $4[15.50]$ & $1[17.00]$ & $4[16.17]$ \\
\hline $\mathrm{T} 2$ & & $0[5.50]$ & $4[20.00]$ & $0[12.50]$ & $4[12.17]$ \\
\hline $\mathrm{T} 3$ & & $0[5.50]$ & 3 [11.00] & $1[17.00]$ & $4[15.83]$ \\
\hline $\mathrm{T} 4$ & & 1 [14.17] & $4[15.50]$ & 0 [8.00] & $4[13.50]$ \\
\hline T5 & & $2[21.50]$ & $4[15.50]$ & 0 [8.00] & 4 [18.33] \\
\hline T6 & & $2[17.83]$ & 3 [11.00] & $1[17.00]$ & $4[10.83]$ \\
\hline $\mathrm{T} 7$ & & 1 [14.17] & $4[15.50]$ & $0[12.50]$ & $4[17.67]$ \\
\hline $\mathrm{T} 8$ & & $2[17.83]$ & 3 [11.00] & $1[21.50]$ & 3 [8.00] \\
\hline T9 (control) & & 2 [15.33] & 3 [11.00] & $0[12.50]$ & $4[13.50]$ \\
\hline$P$ value & & 0.115 & 0.225 & 0.238 & 0.270 \\
\hline
\end{tabular}

Different superscripts within columns differ significantly at $P<0.05$
NDV, but at day 42, all the birds had titres varying from 1:4 to $1: 1024$.

Alike the observed on the antibody titres for influenza and NDV, a wide variation was also observed on the response to inoculation of SRBC (Table 4). In general, the ability to produce immunoglobulins against the xenogeneic erythrocytes was not affected neither by the length of treatment nor the dose of the Probio Enzyme mixture. However, statistical differences were found between the groups regarding IgG production after the first and second inoculation ( $P=0.005$ and $P=0.003$, respectively) and also in the total immunoglobulins produced after the second inoculation $(P=0.044)$. The total Ig produced after the first inoculation was not affected by treatment (Table 4). Following the expected normal development of the immune response, IgG titres after first inoculation were $1: 2$ in three birds, but absent in all the others. After the second inoculation, IgG titres were $1: 2$ to $1: 8$ in 12 birds but remained absent in 15 birds. Only in control group (T9) all broilers presented IgG titres against SRBC; contrasting, in all treated groups (T1-T8) the proportion of birds showing IgG titres varied between none and two subjects. Apart from one bird in T1, all other birds produced detectable IgM against xenogeneic erythrocytes after the first inoculation. After the second inoculation, all broilers (except in one bird in T8) produced detectable IgM titres, which varied from 1: 2 to 1:16 (Table 4).
Both the length of treatment and the dietary level of the mixture significantly influenced the final weight of broilers ( $P=0.037$ and $P=0.015$, respectively). The chickens' BW median was lower when Probio Enzyme mixture was supplied to broilers, whether in short or long treatments. Further, BW decreased with increasing amounts of mixture, particularly when its concentration was higher than $250 \mathrm{~g} / \mathrm{ton}$ $(P=0.031$; Table 5). All the treatment groups showed lower BW compared to control; only the birds from T1 presented a BW similar to those of control. The length of treatment did not affect the absolute or the relative organ weight evaluated (Table 5). However, the amount of the Probio Enzyme mixture affected the relative spleen weight $(P=0.022)$, which was slightly lower when the mixture concentrations were 250 or $1000 \mathrm{~g} /$ ton (Table 5). The treatment group significantly affected the absolute liver weight $(P=0.002)$, which was considerably higher in the control group compared with all the treated groups (Table 5). However, these differences were not transposed to the relative liver weight. The Kruskal-Wallis test suggests that birds from T9 and T1 were heavier. It appeared that the supplement ingested by these chickens at low doses for only 14 days did not affect BW; however, at higher doses for a longer period, the product could not be associated with improved BW in the applied test design. The dietary treatment also influenced the absolute and relative spleen weight ( $P=0.003$ and $P=0.001$, respectively). The median absolute 
Table 4 Immune response after inoculation of sheep red blood cell in broilers. Values in the table represent the median [mean rank]

\begin{tabular}{|c|c|c|c|c|c|c|c|}
\hline \multirow[t]{2}{*}{ Treatments } & & \multicolumn{3}{|c|}{ Immunoglobulins titres 14 days after 1st inoculation } & \multicolumn{3}{|c|}{ Immunoglobulins titres 14 days after 2 nd inoculation } \\
\hline & & Total Ig & $\operatorname{IgG}$ & $\operatorname{IgM}$ & Total Ig & $\operatorname{IgG}$ & $\operatorname{IgM}$ \\
\hline \multirow[t]{3}{*}{ Length (day) } & Control & $2[16.67]$ & $0[12.00]$ & $2[18.50]$ & $3[19.00]$ & $1[20.50]$ & $2[15.67]$ \\
\hline & Short (14) & $1.5[15.38]$ & $0[16.50]$ & $1[13.75]$ & $2[11.50]$ & $0[12.17]$ & $2[12.17]$ \\
\hline & Long (42) & $1[11.96]$ & $0[12.00]$ & $1[13.12]$ & $2.5[15.25]$ & $0[14.21]$ & $2[15.42]$ \\
\hline$P$ value & & 0.433 & 0.059 & 0.513 & 0.232 & 0.181 & 0.507 \\
\hline \multirow[t]{5}{*}{ Probio Enzyme (g/ton) } & 0 & $2[16.67]$ & $0[12.00]$ & $2[18.50]$ & $3[19.00]$ & $1[20.50]$ & $2[15.67]$ \\
\hline & 250 & $1.5[14.50]$ & $0[12.00]$ & 1.5 [15.25] & $2[11.50]$ & $0[8.00]$ & $2[14.83]$ \\
\hline & 500 & 1.5 [15.33] & $0[16.50]$ & $1[13.25]$ & $2[13.42]$ & $0[13.25]$ & $2[13.25]$ \\
\hline & 750 & 1 [14.33] & 0 [14.25] & $1[15.00]$ & $3[16.75]$ & 1 [16.33] & $2.5[16.42]$ \\
\hline & 1000 & $1[10.87]$ & $0[14.25]$ & $1[10.25]$ & $2[11.83]$ & 0.5 [15.17] & 2 [10.67] \\
\hline$P$ value & & 0.810 & 0.540 & 0.542 & 0.516 & 0.096 & 0.700 \\
\hline $\mathrm{T} 1$ & & 1 [12.87] & $0[12.00]^{\mathrm{a}, \mathrm{b}}$ & 1 [13.50] & $2[11.17]^{\mathrm{a}}$ & $0[8.00]^{\mathrm{a}, \mathrm{b}}$ & $2[14.00]$ \\
\hline $\mathrm{T} 2$ & & $2[16.67]$ & $1[21.00]^{\mathrm{b}, \mathrm{c}}$ & $1[11.50]$ & $2[6.83]^{\mathrm{a}, \mathrm{b}}$ & $0[8.00]^{\mathrm{a}}$ & $2[9.50]$ \\
\hline $\mathrm{T} 3$ & & $1[15.33]$ & $1[16.50]^{\mathrm{a}}$ & $1[15.00]$ & $3[16.17]^{\mathrm{a}}$ & $1[16.33]^{\mathrm{a}}$ & $2[15.67]$ \\
\hline $\mathrm{T} 4$ & & 2 [16.67] & $1[16.50]^{\mathrm{a}}$ & $1[15.00]$ & $2[11.83]^{\mathrm{a}}$ & $1[16.33]^{\mathrm{a}}$ & $2[9.50]$ \\
\hline $\mathrm{T} 5$ & & 2 [16.17] & $0[12.00]^{\mathrm{c}}$ & $2[17.00]$ & $2[11.83]^{\mathrm{a}}$ & $0[8.00]^{\mathrm{a}, \mathrm{c}}$ & $2[15.67]$ \\
\hline T6 & & $1[13.33]$ & $0[12.00]^{\mathrm{a}}$ & $1[15.00]$ & $5[10.00]^{\mathrm{a}}$ & $1[18.50]^{\mathrm{a}}$ & $2[17.00]$ \\
\hline $\mathrm{T} 7$ & & $1[13.33]$ & $0[12.00]^{\mathrm{a}}$ & $1[15.00]$ & $3[17.33]^{\mathrm{a}}$ & $1[16.33]^{\mathrm{a}}$ & 3 [17.17] \\
\hline $\mathrm{T} 8$ & & $0[5.00]$ & $0[12.00]^{\mathrm{a}}$ & $0[5.50]$ & $2[11.83]^{\mathrm{a}}$ & $0[14.00]^{\mathrm{a}}$ & 2 [11.83] \\
\hline T9 (Control) & & 2 [16.67] & $0[12.00]^{\mathrm{a}}$ & $2[18.50]$ & $3[19.00]^{\mathrm{a}, \mathrm{b}}$ & $1[20.50]^{\mathrm{a}, \mathrm{b}, \mathrm{c}}$ & $2[15.67]$ \\
\hline$P$-value & & 0.147 & 0.005 & 0.114 & 0.044 & 0.003 & 0.407 \\
\hline
\end{tabular}

Different superscripts within columns differ significantly at $P<0.05$

spleen weight was higher in control than treated groups, and the lowest median values were recorded in broilers treated with $250 \mathrm{~g} /$ ton of Probio Enzyme mixture (T1 and T5). The median of relative spleen weight was higher in $\mathrm{T} 2$ and $\mathrm{T} 7$, which were close to the control treatment (T9). The thymus absolute or relative weight did not differ between dietary groups. However, in broilers fed Probio Enzyme mixture showed slightly higher medians compared with control, particularly when fed $500 \mathrm{~g} /$ ton or $750 \mathrm{~g} /$ ton, respectively.

\section{Discussion}

This study investigated the effects of treatment duration and dose of a probiotics and enzymes mixture (Probio Enzyme, XVET GmbH, Germany) on the immune response and weight of immune organs in broilers chickens. The Probio Enzyme treatment did not affect the antibody responses to NDV or AI vaccination, although in general a decrease in antibody production at day 33 was found compared to day 42 , in either the short and long treatments. These results agree with previous report by Talebi et al. (2008) that found a similar gradual increase in the response to the vaccines between days 28 and 42, even if the authors failed to obtain differences between treated and control groups. Similar results have been also recently reported by Sadeghi et al. (2015), who reported that the dietary inclusion of a probiotic-enzyme mixture had no significant effect on the immune parameters of chickens, but improving the immune response in birds when challenged with a pathogen. However, contrasting reports exist on the probiotics influence over the antibody production (Kabir et al. 2004; Haghighi et al. 2005; Midilli et al. 2008), which rose the hypothesis that in part its effects may be mediated by improved local immune defences (Kabir 2009) and by increased production of modulatory immune molecules, such as interleukins (Zhang et al. 2016).

In the present study, the immune challenged was obtained through the double inoculation of 5\% sheep red blood cells. After the second inoculation, groups treated shortly with $750 \mathrm{~g} /$ ton of the mixture or long-treated with 500 or $750 \mathrm{~g} /$ ton of the Probio Enzyme mixture presented increased or equal total immunoglobulins titres than controls, which were mostly related to changes in IgG production. Similar results were reported by Khaksefidi and Ghoorchi (2006) and by Kabir et al. (2004). In a different approach, testing the oxidative burst of heterophils and monocytes, Stringfellow et al. (2011) found a favourable influence of a probiotic containing lactic acid producing bacteria in the immune response of broilers.

It is believed that, by acting locally regulating the intestinal biota, probiotics improve the growth performance of broiler 


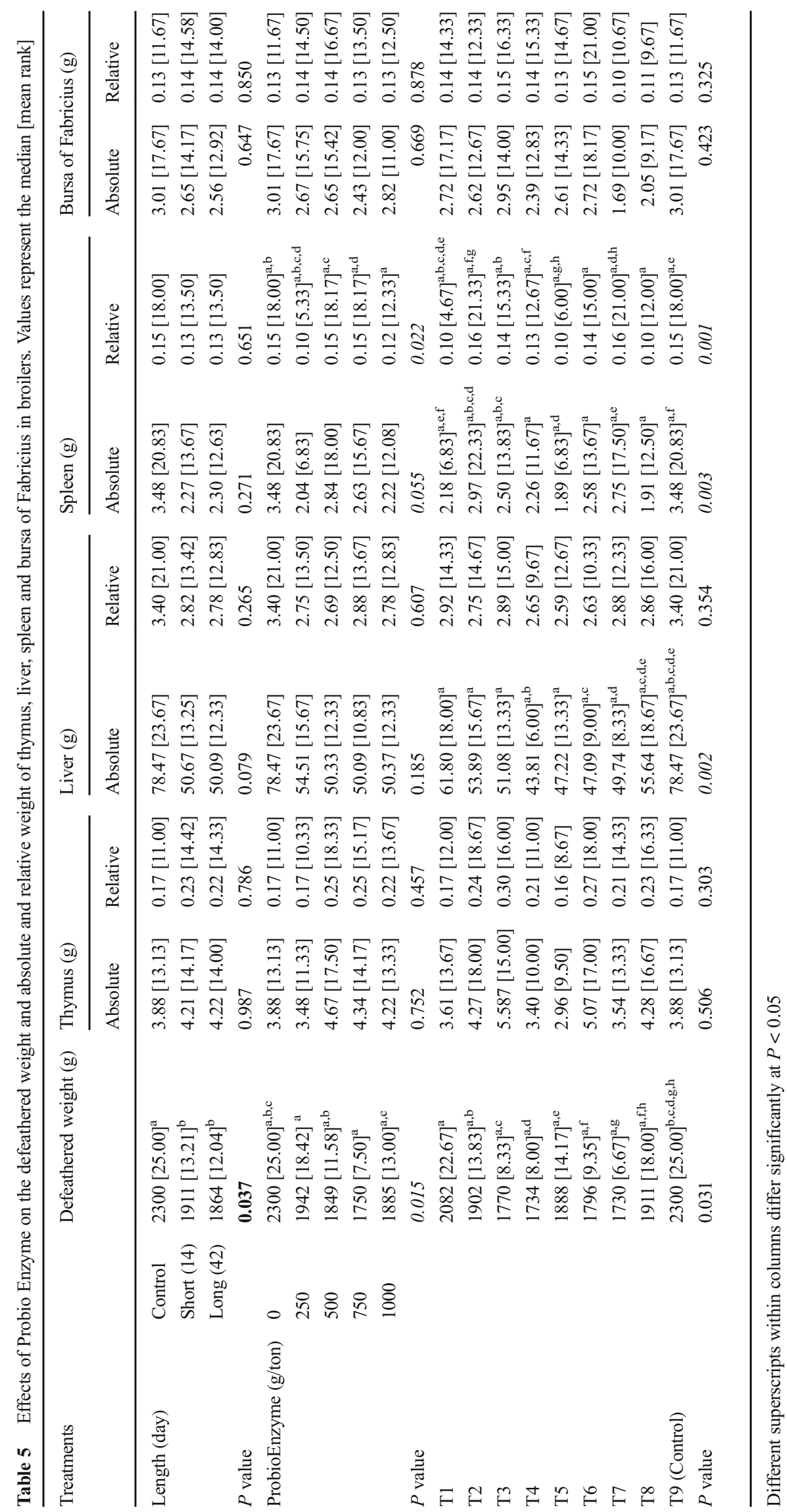


chickens and reduce flock mortality. However, information on the advantages of the use of probiotics on growth performance is still contradictory. In the current study, most of treated groups showed significantly lower BW than control, with exception of T1, contrasting to those reports that failed to demonstrate that probiotics may improve growth (Haghighi et al. 2005; Lee et al. 2010). These differences may be related with the constitution of the probiotics mixture, the route of administration and even with the doses tested (Gaggìa et al. 2010), making difficult a net comparison of the results.

The present study also showed that the absolute or the relative weight of thymus and bursa of Fabricius remained unaffected by treatment, alike it was reported previously by others (Awad et al. 2009), suggesting therefore that the use of the Probio Enzyme mixture should not lower the immune activity based in the central lymphoid organs. The probiotic mixture used in the current study affected both the absolute and the relative spleen weight; it was in general lower in groups treated with the lowest and highest mixture doses, while in the intermediary amounts (500 and $750 \mathrm{~g} /$ ton), the values were identical to those found in controls. Although these findings contrast with those of Naseem et al. (2012), they support the hypothesis of an immune modulatory effect of probiotics on antibody production and an improved avian immune activity. The spleen is related with the final stages of lymphocyte differentiation and the production of memory cells for the secondary immune responses, therefore playing a crucial role in disease resistance (John 1994). Due to our experiment design, no age- or environmental-related effects are expected; hence, the differences in the spleen weight are attributed to the combined effect of the Probio Enzyme mixture and the recent immune challenges.

In conclusion, birds' groups treated with the Probio Enzyme mixture showed in general a satisfactory immune response compared with control, despite the wide variation found in particular after the first vaccine challenge against AI. The length of treatment and the dose of the probiotic mixture modulated differently the immune response and the weight of the spleen, while unaffecting the weight of the central lymphoid organs. Considering all the parameters tested, the most promising combinations of length and amount of Probio Enzyme mixture were represented by short $\times 500 \mathrm{~g} /$ ton $(\mathrm{T} 1)$ and the long $\times 500 \mathrm{~g} /$ ton $(\mathrm{T} 6)$ or the long $\times 750 \mathrm{~g} /$ ton $(\mathrm{T} 7)$. However, additional studies with larger number of animals would be desirable to validate these findings for the industry.

Acknowledgements Financial support by Rasht Branch, Islamic Azad University is gratefully acknowledged.

\section{Compliance with ethical standards}

Ethic rules The procedures have been approved by authors' Institutional Ethics Committee, and care was taken to minimize the number of animals used.
Conflict of interest The authors declare that they have no conflict of interest.

\section{References}

Awad WA, Ghareeb K, Abdel-Raheem S, Böhm J (2009) Effects of dietary inclusion of probiotic and synbiotic on growth performance, organ weights, and intestinal histomorphology of broiler chickens. Poult Sci 88(1):49-56

Bai SP, Wu AM, Ding XM, Lei Y, Bai J, Zhang KY, Chio JS (2013) Effects of probiotic-supplemented diets on growth performance and intestinal immune characteristics of broiler chickens. Poult Sci 92(3):663-670

Chen WL, Liang JB, Jahromi MF, Abdullah N, Ho YW, Tufarelli V (2014) Enzyme treatment enhances release of prebiotic oligosaccharides from palm kernel expeller. Bioresources 10:196-209

Cunningham CH (1971) Virologia Practica, 6th edn. Zaragoza, Acribia, p. 260

Gaggìa F, Mattarelli P, Biavati B (2010) Probiotics and prebiotics in animal feeding for safe food production. Int J Food Microbiol 141: S15-S28

Guarner F, Malagelada JR (2003) Gut flora in health and disease. Lancet 361(9356):512-519

Haghighi HR, Gong J, Gyles CL, Hayes MA, Sanei B, Parvizi P, Gisavi H, Chambers JR, Sharif S (2005) Modulation of antibody-mediated immune response by probiotics in chickens. Clin Diagn Lab Immunol 12(12):1387-1392

Jahromi MF, Altaher YW, Shokryazdan P, Ebrahimi R, Ebrahimi M, Idrus Z, Goh YM, Tufarelli V, Liang JB (2016) Dietary supplementation of a mixture of lactobacillus strains enhances performance of broiler chickens raised under heat stress conditions. Int $\mathrm{J}$ Biometeorol 60:1099-1110

Jin LZ, Ho YW, Abdullah N, Jalaludin S (2000) Digestive and bacterial enzyme activities in broilers fed diets supplemented with lactobacillus cultures. Poult Sci 79(6):886-891

John, J. L. (1994). The avian spleen: a neglected organ. Q Rev Biol 327 351

Kabir SL, Rahman MM, Rahman MB, Rahman MM, Ahmed SU (2004) The dynamics of probiotics on growth performance and immune response in broilers. Int J Poult Sci 3(5):361-364

Kabir SM (2009) The role of probiotics in the poultry industry. Int J Mol Sci 10(8):3531-3546

Khaksefidi A, Ghoorchi T (2006) Effect of probiotic on performance and immunocompetence in broiler chicks. J Poult Sci 43(3):296-300

Lee KW, Lee SH, Lillehoj HS, Li GX, Jang SI, Babu US, Park MS, Kim DK, Lillehoj EP, Neumann AP, Rehberger TG, Siragusa GR (2010) Effects of direct-fed microbials on growth performance, gut morphometry, and immune characteristics in broiler chickens. Poult Sci 89(2):203-216

Macpherson AJ, Harris NL (2004) Interactions between commensal intestinal bacteria and the immune system. Nat Rev Immunol 4(6): 478-485

Midilli M, Alp M, Kocabağli N, Muğlalı ÖH, Turan N, Yılmaz H, Çakır $S$ (2008) Effects of dietary probiotic and prebiotic supplementation on growth performance and serum IgG concentration of broilers. S Afr J Anim Sci 38:21-27

Naseem S, Rahman SU, Shafee M, Sheikh AA, Khan A (2012) Immunomodulatory and growth-promoting effect of a probiotic supplemented in the feed of broiler chicks vaccinated against infectious bursal disease. Revista Brasileira de Ciência Avícola 14(2):109-113

Pourhossein Z, Qotbi AAA, Seidavi AR, Laudadio V, Centoducati G, Tufarelli V (2015) Effect of different levels of dietary sweet orange 
(Citrus sinensis) peel extract on humoral immune system responses in broiler chickens. Anim Sci J 86(1):105-110

Rezaei S, Jahromi MF, Liang JB, Zulkifli I, Farjam AS, Laudadio V, Tufarelli V (2015) Effect of oligosaccharides extract from palm kernel expeller on growth performance, gut microbiota and immune response in broiler chickens. Poul Sci 94:2414-2420

Sadeghi AA, Shawrang P, Shakorzadeh S (2015) Immune response of salmonella challenged broiler chickens fed diets containing Gallipro®, a Bacillus subtilis probiotic. Probiotics and antimicrobial. Proteins 7(1):24-30

SPSS (1997) SPSS Base 7.5 for windows. SPSS, Chicago, IL

Stringfellow K, Caldwell D, Lee J, Mohnl M, Beltran R, Schatzmayr G, Fitz-Coy S, Broussard C, Farnell M (2011) Evaluation of probiotic administration on the immune response of coccidiosis-vaccinated broilers. Poult Sci 90(8):1652-1658
Talebi A, Amirzadeh B, Mokhtari B, Gahri H (2008) Effects of a multistrain probiotic (PrimaLac) on performance and antibody responses to Newcastle disease virus and infectious bursal disease virus vaccination in broiler chickens. Avian Pathology 37(5):509-512

Wang Y, Gu Q (2010) Effect of probiotic on growth performance and digestive enzyme activity of Arbor Acres broilers. Res Vet Sci 89(2): 163-167

Yang Y, Iji PA, Choct M (2009) Dietary modulation of gut microflora in broiler chickens: a review of the role of six kinds of alternatives to in-feed antibiotics. World's Poul Sci J 65(01):97-114

Zhang L, Zhang L, Zhan X, Zeng X, Zhou L, Cao G, Chen A, Yang C (2016) Effects of dietary supplementation of probiotic, Clostridium butyricum, on growth performance, immune response, intestinal barrier function, and digestive enzyme activity in broiler chickens challenged with Escherichia coli K88. J Anim Sci Biotechnol 7:3 